\title{
9 1/2 EXEMPLARY THOUGHT EXPERIMENTS
}

\author{
JOANNA WALSH
}

Writer and $\mathrm{PhD}$, University of East Anglia

\section{ABSTRACT}

Where is the face in interface?

Where is the soft in ware?

What is soft and where?

What happens when a woman whose private acts of abjection (emotional labor, unpaid domestic work) that support - against her will — a political and economic status quo that perpetuates her situation, is offered a range of online platforms on which to screen her self?

How does a woman in front of a screen begin to develop an online persona from which to perform this self? A number of thought experiments demonstrate (as demonstration is a screen mode) some of the available modes and their parameters.

INTRODUCTION “'The universal has been, and is continually, appropriated by men,' leaving women consigned to theorizing from particularities. "1 Sianne Ngai quotes Monique Wittig in "Bad Timing."

"The more feminine the example, the more exemplary the example. As if femininity itself were a hyperbolic mode of exemplarity? Or, to turn a famous phrase of Lacan's, structured 'like' an example?" Sianne Ngai, Ugly Feelings.

"What's personal, local, and sensual about the perception of the historical present often produces skepticism about its historical actuality and exemplarity. ${ }^{, 3}$ Lauren Berlant, Cruel Optimism.

\section{SWITCH}

"Real pain, as real as our own, would exist in virtue of the perhaps disinterested and business like activities of these bureaucratic teams, executing their proper functions." Dennett, Toward a Cognitive Theory of Consciousness.

Where do I begin?

("I" has begun already.) 
Functionalists hold that mental states are defined by the causal role they play in a system. In John Searle's 1980 Chinese Nation thought experiment, pain is a point in time. It occurs when enough components say it does. Say there are switches in a system and these switches are called pain, and if enough switches flick on at the same time, pain exists. Say there's a woman working alone in a room at a screen and the screen screens her privacy, the privacy which she also is, yet she's allowed to appear onscreen if she does not admit that privacy. Let's say she chooses an avatar that gives her an onscreen face, a face that does not look like a woman who has undergone any private experience whatsoever, which is the most fortunate female inter-face, a face that is still in front of the logic gates which have not yet closed behind her, admitting her to any kind of experience whatsoever. Let's say the logic gate is a pain switch.

A logic gate has a single binary function. From a dual input it produces a single output. It does this by way of a conjunction, like AND " $\wedge$ ” or OR " $\vee$ ", which is a non-exclusive OR, and XOR which is an exclusive OR in which only one thing is true, or the other. This logic gate's XOR function is PAIN/NOTPAIN. The pain is not of any specific sort, physical or mental. It is the pain the woman is feeling. Any sort of pain may go through the gate so long as she is willing to call it pain.

Say there are enough women sitting alone, each in a room, each in front of a logic gate to cause pain to the entire system. Do they or do they not flip the switch? If enough of them flip the switch, something can be called pain.

Where is that pain located? Is it located in each woman, her particular pain, or is it located in the system? If it is located in the system, in what sense can the system be said to feel pain?

If enough women sitting in front of enough screens flip the pain switch, will pain have been felt? And how many is enough? How many women must make the decision to flip the switch before the system can be said to be in pain? And how much in pain does the system have to be in order that the pain of the women be acknowledged, even the pain of the women who wish to save face and retain their avatar? In what part is pain allowed to each of the women, and is it evenly distributed yet ${ }^{5}$ if some of the women are more in pain than others but each has only one switch?

Does the amount of pain each woman feels change once the woman feels herself to be part of a system?

To lay claim to pain is to lay claim to experience. It is also to have the option to claim experience only as pain. To save face, there is something to be said for staying in front of the logic gate, refusing to go in.

\section{XOR}

What about the pain caused by making the decision, by having to make the decision to choose whether to flip the pain switch or not, by having to make the decision to choose whether to save face or to be the pain? This might be a slight pain, pain as byproduct, or might be a major part of the pain, greater than the pain registered. 
In her prison memoir, ${ }^{6}$ the Irish writer Margaretta d'Arcy describes how women political prisoners dealt with pain that might otherwise cause them to "go under." They dealt with it as a system. They would mention the incidence of pain to each other, in strictly unemotional terms, like flipping a switch. Thus the pain would be dispersed across space and time

\section{FUNCTION}

My hair is shingled, and the longest strands are about nine inches long. In order that tones of voice may not help the interrogator, the answers should be written or, better still, typewritten." "-Alan Turing, Computer Machinery and Intelligence.

How should I write this

I

Who have no voice except words onscreen?

Who have no voice except words IRL and words onscreen?

Who have no writing classes except onscreen.

Who have no writing classes except memes and content and also the hedge on a wet day.

Who have no work with words except the work of calling children to persuade them. To put on shoes, to eat, to clean their teeth, to come away from the hedge on a wet day. To go, always to go. To go and to come back: I call, my function. Theirs. I have no voice except this calling voice, which does not expect a response. I have no voice except this other voice, which declares: the onscreen voice. The first voice feels like function, the second feels like fame. It is the voice of many people. I participate in it; its vocabulary is unusual. It does not taste like mine.

What is called upon in the first voice? That I am self-calling. Who calls me to self-call: the second voice. What is called upon in the second voice? That I am called upon to self-call. And then I do not call in my voice but in another voice but that I may expect a response. A response is not an answer. What is called upon in the first voice? That I do not call in any voice but my own but I may expect no response. The first voice makes things happen IRL. The second voice makes nothing happen, like poetry makes nothing happen. The second voice is polis. The first voice is private. In the first voice, I express my function. In the second, I declare it.

(All functions are naturally private and local until declared. Declaration makes my local values global! Global values are explicit; local implicit, which makes them similar to a class definition. Local functions cannot act at a global level.)

A self-calling function, once declared, will continue to call itself. I do not have to be named to be called: my name is optional, in which case my function is anonymous, my name local only to my function body. I can express my function without being named, but then I must express myself anew each time. A self-executing anonymous function, I can be called using a variable name, but I cannot continue to call myself 'til I'm defined.

What defines me? A declaration! 
A declaration gives my function parameters. My parameters can be my name, argument, or functions. I cannot declare myself. What is declared as my function is true across all uses of my function, but my function is not my use. I may have private functions other than my use. I may have public uses that do not express my function. What I express as my function may change from use to use.

(A parameter? An argument passed to the function.)

(A statement? Comprises the body of the function.)

(You need to know neither if you can call its name.)

If my function is expressed I do not have to be called. I will self-invoke if my expression ends in (). (But if my function is declared I cannot invoke myself.)

(My expressions are always in parentheses.)

My functions can be used as my values, which are variable: they can be declared even after they have been executed. Declared functions are not executed immediately. They are "saved for later use," and will be executed later, when they are called up (invoked). My function can also be my object, having both a property and a method. As an object I am easier to isolate, easier to use. My function is the method of its object, the property of its object; it may also create objects itself: fun. Fun.caller is the function that most recently called fun.

(In other words

Procedural AI knows how to clean a room; declarative knows how to tell it to.)

\section{OR}

A woman sits in front of a screen. Each word is a binary logic gate. Each XOR is an exclusive gate: something of her must be excluded. Each OR is a non-exclusive gate, allowing for compromise. Which is like

The composition of self as writing

In which

Words only come before OR after how things are, each

Word a binary gate.

(Don't take any thing

For granted!)

I am in front of the binary gate of people OR (non-exclusive $O R$ ) things. The nature of the gate is a request to assign value in the economy of things, that is things coming and going. You do not want too many things to go, you also do not want too many things to come. So the economy of things is a fight between things and people. As the woman of the house, I preside over it. It is through my gate that things come and go. I also go through the gate, and this going is something I preside over too. That's how things are. Here are some of my gates, for instance: does it cost more to wash the clothes by hand, and/or to earn the money to buy a washing 
machine, and/or earn more money to send the clothes to the cleaner $?^{8}$ What time will be spent on each activity, and what time would be spent learning enough to get the job to pay for the washing machine or to pay for the cleaning? And how much more will any of these things cost than washing the clothes with a scrubbing brush or alternatively, my tongue? Also: When is a washing machine worn out? And: When is a person worn out? And also, when are clothes worn out? and when they are, should they be thrown away or given to charity or sold on eBay? Which entails: How can a thing be forced onto a screen? And: How can a person be forced onto a screen? And: What is the use of this forcing? I am asked to judge each thing by its function, which is use. I am also asked to judge myself by use which is my function. Part of my use is how useful I am in judging. Who asks me to judge? It does not feel like me, though I put myself to use very well OR (non-exclusive OR) I am a very good judge of the work being done. In order to live in this world onscreen OR (non-exclusive OR) that world offscreen, I do this. It grants me the freedom also to be a thing onscreen, and to extend my work of sorting, and being sorted, virtually.

\author{
(What's the use in taking \\ things \\ so personally?)
}

Instead, why wouldn't I hang out in a temple of frozen goods

Or its online equivalent. Where everything appears to be?

\title{
USE
}

(Making a self through collecting photographs of things that self would like to have.)

I'm wondering what "I" can be when it's not being of use. There's a shop near me called Objects of Use, and it's a minimalist shop of handcrafted things. These things can be used just the same way manu-factured ${ }^{9}$ things are used, but it takes some time to recognize what some of them can be used for. The shop has far more things in it that a minimalist could use, and its piling up is what makes the things attractive. Its piling up and its neat triage. Everyone knows the most successful artists repeat the same thing over and over again. Or so I'm told. Repeatedly. As soon as you have enough to stop worrying, you have enough to worry about stopping. But things look so good when they're waiting on the shelf, all looking useful, none of them in use, none of them having been used, things I've never thought of using such a thing as a "reindeer leather coin purse" or an "Onsen basket." They look good when they're ready for use, better than when being used and better than when they have been used.

The shop is repeated onscreen where it is divided into sections.

There is especially, a section of objects called "work."

There is especially a section of objects called "person."

"The intellectual, C. P. Snow believes, is always a luddite," wrote A. M. Hilton in 1963. "He seeks individuality." ${ }^{10}$ Opposing "individuality" to technology, Hilton didn't believe that handcrafted things would persist once manufactured things had blurred their aesthetic. But Hilton didn't predict the mass production of "individuality." Hilton didn't believe in the persistence of 
things as process, or of things as things. Any thing might very well be replaced by any other another.

A. M. Hilton sought individuality by, like C. P. Snow, using her initials not her name which screened (non-exclusive OR) her gender, or defaulted (XOR exclusive OR) in 1963 to male as at that date woman (STRIKETHROUGH=EQUALLED) intellectual. A. M. Hilton had no Wikipedia page before 2019 when I caused one to be made which caused her individuality to be screened in the sense of "overwritten" by the revelation of her gender, or (NON-EXCLUSIVE OR or XOR EXCLUSIVE OR) screened in the sense of "projected" by the revelation of her gender.

And, as for me, no one sees me when I'm being useful offscreen. There's nothing that can be projected. Have I been granted a residency in a place from which I can say nothing? If I speak from this place, will it immediately pay back whoever granted me this residency? Is there anywhere else I can be, my screen currency — having been a) being kind of ok looking and b) being hopeful — declining both by duration and by choice? Any successful self is repetition. Then there is the keeping on making, which is keeping on making a self by hand, even if it is the self.

\section{SOUND}

Life offscreen has a strange blank quality. I listen but hear nothing.

How strange, really I have always wanted

The chance to stop being.

I've always been friends with silence

(Look how I'm shouting this!)

Silence is a sign of system failure.

Silence is also a system (look what communicates in parentheses!

Look what data is gathered!)

On Youtube, a video of a lecture by the artist Hito Steyerl: ${ }^{11}$ a research engineer is breaking windows to teach AI the sound of breaking glass. "It feels strange the first time you do it," says the engineer whose function is not normally to break windows. "The second time it's exciting and the third time it becomes work. That's because you have to keep doing it over and over again."

In 1869, Charles Baudelaire broke panes of glass, but they weren't his windows. He yelled, make life beautiful again! at a man who could provide no glass that screened Real Life with pleasant colors, then he smashed the glazier's goods, worrying all the time only for the good of his own soul. Baudelaire wrote about breaking windows once, but somebody's windows are always being broken. Baudelaire was smashing the windows of sentimentality that belonged to Arsène Houssaye who had written a poem, Le Chanson du Vitrier about a starving glazier who could get no work because no windows were being broken (this is a different poem again from Jacques Prevert's twentieth-century Chanson $d u$ Vitrier in which the glazier is part of a system of working-class tradespeople laboring in happy reciprocity). By breaking the panes belonging to the glazier that-like Steyerl's glass - had never been used as windows, Baudelaire cuts out the middleman of function. Whatever: both Baudelaire and Houssaye's glaziers end up out of work. 
"A thought experiment," says Steyerl, "is cheaper and much faster" than a proof IRL. But glass only speaks when it is broken. Steyerl, running the engineers' dialogue through a Markov generator, ${ }^{12}$ found it produced the window as a speaking subject. But still not the glazier. Phones recognize the sounds of their own bodies breaking, the screen that keeps their insides working. The engineers Steyerl filmed were breaking windows in order to develop private security technology as a substitute for the police, producing "a luxury version of a war zone." A speech act makes what's private, public. "Artificial Stupidity," she said, "can break every window in every street." But "windows," said another of the engineers, "are a lot harder than you think.... We are actually taking a hammer and breaking a window. So this is reality." "As an artist," says Steyerl, "you are always being accused of being completely inconsequential and having no effect at all on the real world."

What is the difference between poetics and poesis? Are either of them politics? Whose windows is it ok to break with art, and when? One kind of work is the work of writing.

Another is the work that writing can do. I am talking to my friend Caroline, who is an artist. We are working together right now on a speaking robot that is a body without organs, in collaboration with some women who are activists IRL. She will wire its body and I will write its words. The activists are its material. And we are always saying to each other,

How can we make art that has any kind of effect in the real world?

And also:

Is it enough to depict action?

Switch off social media: dust settles on the work of self. Time to hear things IRL, accidental things. Hearing onscreen is replaced by reading, and there's such clamor in writing. There are times when I wonder if I could backpedal on identity, when my identity is so bound up with what I write there. Is it possible to break that squared circle that is worded silence?

\section{WORK}

(Because people onscreen complain that it is work.)

Is it work like the work of kneading meat for meatloaf in Chantal Akerman's film Jeanne Dielman, which is also the work of making work into film which is also work done by its subject, who is simultaneously working at being the real-life actor and filmmaker, Delphine Seyrig? Or is it like the work of sewing underwear in an underwear factory in Elfreide Jelinek's novel Women as Lovers, which is also the work of making work into writing, which is work done by the writer but not by her subjects, the word-women Paula and Brigitte?

Or is it like screen work?

Is it like the work of writing another word onscreen, which is also being a subject onscreen? Is it like the work of waiting for another word for a novel or the work of waiting for another word for a screenplay? Is it like the work of waiting for the right word for a Linkedin profile? Is it like the work of waiting for the right word for a dating profile?

Or is writing more like the work of waiting that is work done offscreen? Is it like the work of waiting for a bus if you don't have a car, or is it like the work of waiting to be paid, if you don't have the money, or is it like the work of paying attention? Is it like the work of waiting in any kind of waiting room - medical, legal, procedural —which is a place built for waiting, or is it like 
the work of waiting in a bar, waiting tables in a bar which are also built for waiting, or is it like the work of also waiting in a bar, waiting for someone to arrive who does/does not arrive, which is not called work but is done in time bought by work elsewhere, which I guess could be called a date, because it is a place but also a time, as all work is about time? These are all kinds of relational work because they are work done in relation, and these are all kinds of work I have done.

Both these last two kinds of waiting work rely on paying and also on paying attention. In the first kind of work you pay attention in order to be paid and in the second you pay attention in order to pay. And both these kinds of work rely on spending time, on a gap of space that can be crossed by spending time, or a gap of time that can be crossed by attention paid.

Or it is more like the kind of work that happens on any day that has no date- they are just $24 \mathrm{~h}$ and then $24 \mathrm{~h}$ - which is the work of spending time waiting for someone to arrive when you've worked at the relational work of waiting on and for relations and the work of waiting on and for work onscreen all day and it's about time someone came but someone doesn't come, or is it like the work of having worked at this waiting all day, but which is the work of spending time waiting for no one to come? These are also both kinds of work I have done.

And of all these kinds of work the worst kind was the work of waiting for someone who does not come, which means there is no end to the other kinds of work, and the best kind of work is waiting for no one to come, that and the work of writing.

What I am writing about is, where is my workplace? Also what I am writing about is, where isn't? Also I should write about when is my workplace and also what am I working for and who am I working for? Not to mention what am I working on and is this working for me? Onscreen, but also on myself. These are my places of work, or rather my work times, though what I do onscreen is sometimes called work and what I do offscreen is never called work. Why do I work in these places? Because they are places it has been easy for me to be placed in, and because I have time to spend. Also because sometimes, not always, I am paid with money or otherwise in attention paid.

Why spend all this time while doing the work of waiting at the same time working on making a self, a self being a bounded thing that others can recognize because it does this and not this, rather than an unbounded thing of which anything can be asked or commanded, which are baggy activities that have no edge, which won't get you far in the work of self?

\section{XOR}

is writing a self like the work of being onscreen complaining about the work of writing?

(Is writing a kind of complaint, because it allows me to complain?)

(But I do not want my writing to be made of complaint.)

(And I do not want my self to be made of complaint. ${ }^{13}$ )

(I also don't want my self to be made of compliant.)

(But I can't help my self being made of writing.) 


\section{NOTHING}

"You don't need to feel guilty for throwing a gift away. Just thank it for the joy it gave you when you first received it." 14 _Marie Kondo, The Life-Changing Magic of Tidying Up.

(Writing is two kinds of work.

One kind of work is the work of writing.

Another is the work that writing can do.)

When do you abandon an identity onscreen? I mean, when do you stop writing it?

I stopped writing on Facebook, I stopped writing on Instagram. Only Twitter was left, and Twitter was nothing but writing.

One thing about the screen is you can get something for nothing.

Another thing about the screen is you can get nothing for something.

Another thing about the screen is that nothing can become something.

And another thing about the screen is that something can become nothing.

The second is capitalism.

But the first is art.

Or art is also (non-exclusive OR) capitalism because, as Chris Kraus wrote, "Art will always be transactional,"15 and the art of the transaction is also the art. The art of the transaction is a personal art and that art takes place between persons. It is a very personal art because sometimes those persons are the only ones that see it.

The problem with the screen is the same problem as the problem I had with someone who wanted me to help him rehearse to audition for the part of King Lear, a part he didn't get. He asked me to listen to his lines and one line that came out blank: "Our basest beggars are in the poorest things superfluous." " Or to put it another way "I got plenty of nuttin." Or "I'm a man of means by no means." Why does it take so many words to describe what you haven't got? Anyway, he didn't get it and I couldn't ask, what is it about nothing you don't get? just as Goneril and Regan couldn't bring themselves not to be polite.

Googling "poetry makes nothing happen," ${ }^{17}$ answers.com ${ }^{18}$ reminds me it is a line by W. H. Auden, then it asks me:

Why does nothing happen when you step on the gas?

What happens if the president does nothing to a bill?

What makes poetry different from other writings?

Does eating nothing make you fat?

What will happen if nothing is done about pollution?

Nothing will happen in 2012?

How can you make money from nothing?

What makes nothing nothing?

How can you make your friend unmad at you? ${ }^{19}$

How do you make dip with nothing? 
What to do if your into your best friends boyfriend $i$ wont see him again but $i$ will be mad if nothing happens while i have the chance to make something happen?

How to make money from poetry?

I began to write poetry as soon as I had enough money. In other words, when I had enough things, material things, and enough money to convert into things at a steady rate in the thing economy. It's not easy to predict when enough is enough, but it's easy to feel it when it happens. I had no idea that one side effect of having enough things would be writing poetry.

Writing can be a kind of apology for power.

There is no such thing as poverty of language.

\section{TEST}

Read the following paragraph and answer the questions:

Performativity is language that effects change. It is language that changes affects. Performativity yearns: it lies to the present and tells the truth in another dimension. It protests what is AND compensates for what is not very evenly distributed yet. In How to Do Things with Words, J. L. Austin wrote that to make a speech act that declares its function is an "explicit" performance, but that to express a function privately is an "implicit" performance. Binary information can have one of two possible states: true or false, respectively or, less emotively, the values 1 or 0 . J. L. Austin wrote that performative speech acts do more than describe a state, so cannot be assigned a value: true or false. Instead, a performative speech act that declares functions it cannot self-call, he called "unhappy." If its functions accord with its declaration, he called it "happy." An unhappy declaration can be an error, which, declaring itself, can be corrected, or, more seriously, a mistake, which cannot. Hap contains the element of chance. It is by chance our affective positions visit us, or perhaps by fate. "If someone has a fate, then it's a man," writes Elfriede Jelinek in Women as Lovers. "If someone gets a fate, then it's a woman."20

\section{Questions:}

1. J. L. and A. M. both conceal their gender by using their initials. Whose condition is "happy," and whose is "unhappy"?

2. J. L. is a man and A. M. is a woman. In concealing their respective genders, is one of their performances "implicit" and the other an "explicit"? Which?

3. If John Searle wrote in 1989 that "the successful performance of the speech act is sufficient to bring about the fit between words and world," ${ }^{21}$ can A. M. = J. L. be considered a successful symmetric Boolean relation?

4. If, as Bach and Harnish wrote in $1982,{ }^{22}$ performatives are successful only insofar as recipients infer the intention "implicit" in the meaning, what can be inferred from J. L./A. M.'s respective works of self?

5. If J. L. and A. M. both deprive themselves of gender, is this effect "transformative" (according to Kosofsky Sedgwick) either in a) the purpose of the writer XOR (EXCLUSIVE OR) b) the inference of the reader (according to Harnish/Bach) OR (INCLUSIVE OR) both? Is this intent to cast off gender cultural XOR (exclusive OR) physical OR (inclusive OR) both?

6. Can things do themselves? What kind of speech act is poetry? 
7. If Judith Butler says performativity is "that reiterative power of discourse to produce the phenomena that it regulates and constrains," ${ }^{23}$ what is the illocutionary force of silence?

8. In making this list of questions, what sorts of explicit and inexplicit speech acts do I commit?

\section{EXPERIMENTAL EVIDENCE OF MASSIVE-SCALE EMOTIONAL CONTAGION THROUGH SOCIAL NETWORKS ${ }^{24}$}

"Emotional states can be transferred to others via emotional contagion, leading people to experience the same emotions without their awareness. "25

Apparently, these experiments have been done.

\section{ENDNOTES}

1. Sianne Ngai, "Bad Timing (A Sequel). Paranoia, Feminism, and Poetry," in differences: $A$ Journal of Feminist Cultural Studies, Vol. 12, No. 2 (2001), 1-46, p. 4.

2. Sianne Ngai, Ugly Feelings, (Cambridge: Harvard University Press, 2007), pp. 148-9.

3. Lauren Berlant, Cruel Optimism (Durham: Duke University Press, 2001), p. 64.

4. Daniel Dennett, "Toward a Cognitive Theory of Consciousness," in Brainstorms:

Philosophical Essays on Mind and Psychology (Cambridge: MIT Press, 1981), p. 167.

5. "The future's already here, it's just not very evenly distributed yet." This possibly apocryphal remark is believed to be the work of William Gibson, and was first credited to him in Scott Rosenberg's, "Virtual Reality Check, Digital Daydreams, Cyberspace Nightmares," in The San Francisco Examiner, April 19, 1992. Source: Quote Investigator

$<$ https://quoteinvestigator.com/2012/01/24/future-has-arrived/> [accessed 15 March, 2017].

6. "By passing's on each other's personal problems, the girls sympathise with one another and so on, like a chain, thus all problems and sadnesses become collective." Margaretta d'Arcy, Tell Them Everything (Galway: Women's Pirate Press, 2017), p. 78.

7.Alan Turing, "Computing Machinery and Intelligence," in Mind 49 (Oxford: Oxford University Press, 1950) <https://academic.oup.com/mind/article/LIX/236/433/986238> [accessed 1 February, 2017].

8. "It is interesting to note that machines designed for the use of the individual (for example, machines to provide household assistance, such as vacuum cleaners) come very late in the industrial development of society since they replace the most poorly paid workers." A. M. Hilton, Logic, Computing Machines, and Automation (London: Cleaver-Hume Press, 1963), p. 370

9. From the "classical Latin manū, ablative singular of manus hand". OED, $<$ https://www.oed.com/view/Entry/113769?isAdvanced=false\&result=1\&rskey=WRmAE7\&> [accessed 20 December 2019].

10. A. M. Hilton, Logic, Computing Machines, and Automation, p. 374.

11. Hito Steyerl, "Language of Broken Glass.",

$<$ https://www.hkw.de/en/app/mediathek/video/69577> [accessed 24 February 2019]. 
12. A Markov generator tells you the probability of future outcomes based on knowledge of a previous event, e.g., predictive text. A Markov generator uses probabilistic logic, assigning probabilities in such a way as to maximize entropy.

13. I have a nominative doppelgänger on Twitter whose tweets are almost always customer complaints, e.g., "@Primark Visited the London Oxford St branch \& was impressed by the new nail bar, but not with the woman who worked there. After ignoring me she finally looked up from her phone. I asked a simple question if they had OPI nail polish she said no then dismissed me by saying bye \#rude." Twitter < https://twitter.com/jo_walsh1980/status/1116834882787979266> [accessed 23 May 2019].

14. Marie Kondo, The Life-Changing Magic of Tidying Up (London: Vermillion, Penguin, 2011), p. 128.

15. Chris Kraus, Social Practices (California: Seimotext(e), 2019), p.11.

16. William Shakespeare, King Lear (London: The Arden Shakespeare 1997), p. 255.

17. W. H. Auden, "In Memory of W. B. Yeats," in Auden: Poems (London: Everyman, 1950), p. 78.

18. answers.com $<$ https://www.answers.com/Q/What_was_the_poetry_makes_nothing_happen> [accessed 13 February 2019].

19. "talk to her tell her that $\mathrm{i}$ am sorry for whatever $\mathrm{i}$ did if she says nothing back she is not a true friend"

20. Elfriede Jelinek, Women as Lovers (London: Serpent's Tail, 1994), p. 3.

21. John Searle, "How Performatives Work," in Linguistics and Philosophy, Vol. 12, No. 5, (October, 1989), 535-88 (p. 547).

22. K. Bach and R M. Harnish., "Linguistic Communication and Speech Acts," in The

Philosophical Review, Vol. 91, No. 1 (1982), 134-8.

23. Judith Butler, Bodies that Matter: On the Discursive Limits of "Sex" (Abingdon: Routledge, 2011), p. xii.

24. A. D. I. Kramer, J. E. Guillory, and J. T. Hancock, "Experimental Evidence of Massive-Scale Emotional Contagion through Social Networks," PNAS, Vol. 111 (2014) 8788-90 (p. 8788 ).

25. Ibid.

\section{REFERENCES}

d'Arcy, Margaretta. Tell Them Everything (Galway: Women's Pirate Press, 2017).

Auden, W. H. “In Memory of W. B. Yeats,” in Auden: Poems (London: Everyman, 1950).

Bach, K., and R. M. Harnish. "Linguistic Communication and Speech Acts," in The

Philosophical Review, Vol. 91, No. 1 (1982), 134-8.

Berlant, Lauren. Cruel Optimism (Durham: Duke University Press, 2001).

Butler, Judith. Bodies that Matter: On the Discursive Limits of "Sex" (Abingdon: Routledge, 2011).

Dennett, Daniel. "Toward a Cognitive Theory of Consciousness," in Brainstorms: Philosophical Essays on Mind and Psychology, (Cambridge: MIT Press, 1981). 
Hilton, A. M. Logic, Computing Machines, and Automation (London: Cleaver-Hume Press, 1963).

Kondo, Marie. The Life-Changing Magic of Tidying Up (London: Vermillion, Penguin, 2011).

Kramer, A. D. I., J. E. Guillory. and J. T. Hancock. "Experimental Evidence of Massive-Scale Emotional Contagion through Social Networks," PNAS, Vol. 111 (2014) 8788-90 (p. 8788).

Kraus, Chris. Social Practices, (California: Seimotext(e), 2019).

Jelinek, Elfriede. Women as Lovers (London: Serpent's Tail, 1994).

Ngai, Sianne. "Bad Timing (A Sequel). Paranoia, Feminism, and Poetry," in differences: A Journal of Feminist Cultural Studies, Vol. 12, No. 2 (2001), 1-46.

Searle, John. "How Performatives Work," in Linguistics and Philosophy, Vol. 12, No. 5, (October, 1989), 535-88.

Rosenberg, Scott. "Virtual Reality Check, Digital Daydreams, Cyberspace Nightmares," in The San Francisco Examiner, April 19, 1992.

Shakespeare, William. King Lear (London: The Arden Shakespeare 1997).

Steyerl, Hito. "Language of Broken Glass."

$<$ https://www.hkw.de/en/app/mediathek/video/69577> [accessed 24 February 2019].

Turing, Alan. "Computing Machinery and Intelligence," in Mind 49 (Oxford: Oxford University Press, 1950) $<$ https://academic.oup.com/mind/article/LIX/236/433/986238> [accessed 1 February, 2017].

\section{AUTHOR BIO}

Joanna Walsh is a multidisciplinary writer for print, digital, and performance. The author of seven books including the digital work, seed-story.com, her latest book, Break.up, was published by Semiotext(e) and Tuskar Rock in 2018. She also works as a critic, editor, and teacher. She is a UK Arts Foundation fellow, and the founder of \#readwomen, described by The New York Times as "a rallying cry for equal treatment for women writers." She earned her PhD in Creative and Critical Writing at the University of East Anglia. 